Original Research Paper

\title{
Pengaruh kompos kotoran kuda terhadap pertumbuhan Kacang panjang (Phaseolus vulgaris L)
}

\author{
Ahmad Raksun ${ }^{1 *}$, Lalu Japa ${ }^{1}$, I Gde Metha ${ }^{1}$ \\ ${ }^{1}$ Program Studi Pendidikan Biologi FKIP Universitas Mataram
}

Article history

Received: August $3^{\text {st }}, 2018$

Revised: September $20^{\text {st }}, 2018$

Accepted: October 4t 2018

Published: November $21^{\text {st }}$,

2018

*Corresponding Author:

Ahmad Raksun,

Program Studi Pendidikan

Biologi FKIP Universitas

Mataram, Indonesia

Email:

ahmadunram@unram.ac.id
Abstract: The availability of nutrients in the soil is one of the factors that can ditermine plant growth. One effort that can be done in overcoming the lack of nutrient is by giving compost to agricultural land. Various research on the effect of compost on plant growth indicate that composting in growing media can increas plant growth. Base on the description above. we conducted research to find: (1) the effect of horse manure compost on the growth of long bean on the agricutural land of Sukarara Village, (2) the dosage of horse manure compost that must be added to the Sukarara farm land in oder that long bean can grow optimally. Rrandomized block design with eight replicates were used in this research. The data was analyzed using Anova.The result of this research are: (1) the use of compost has significant effect on the length of the steam and number of long bean leaves, (2) the optimum dosage of compost that must be given to the Sukarara farm land in oder that long bean can grow optimally is $2,0 \mathrm{~kg}$ compost for $1 \mathrm{~m}^{2}$ farm land. Based on the results of this research, it is recommended that farmers in Sukara Village use horse manure compost at a dosege of $2,0 \mathrm{~kg}$ for $1 \mathrm{~m}^{2}$ of land on agricurtural land that wil be planted with long beans

Keywords: horse manure compost, long bean growth

Abstrak: Ketersediaan unsur hara dalam tanah merupakan salah satu faktor yang dapat menentukan pertumbuhan tanaman. Salah satu upaya yang dapat dilakukan dalam mengatasi kurangnya unsur hara adalah dengan pemberian kompos pada lahan pertanian Berbagai hasil penelitian tentang pengaruh kompos terhadap pertumbuhan tanaman menunjukkan bahwa pemberian kompos pada media tanam dapat meningkatkan pertumbuhan tanaman. Berdasarkan uraian di atas tim peneliti melakukan penelitian yang bertujuan untuk mengetahui: (1) pengaruh kompos kotoran kuda terhadap pertumbuhan kacang panjang pada lahan pertanian Desa Sukarara, (2) dosis kompos kotoran kuda yang perlu diberikan pada lahan pertanian Desa Sukarara agar tanaman kacang panjang dapat tumbuh secara optimal. Dalam penelitian ini digunakan rancangan acak kelompok dengan delapan ulangan. Data penelitian dianalisis dengan analisis sidik ragam. Hasil penelitian menunjukkan bahwa (1) penggunaan kompos pada lahan pertanian Desa Sukarara berpengaruh nyata terhadap panjang batang dan jumlah anak daun kacang panjang, (2) dosis optimum kompos yang perlu diberikan pada lahan pertanian Desa Sukarara agar kacang panjang dapat tumbuh secara optimal adalah $2,0 \mathrm{~kg}$ kompos untuk $1 \mathrm{~m}^{2}$ lahan pertanian. Berdasarkan hasil penelitian ini, direkomendasikan kepada petani di Desa Sukarara menggunkan kompos kotoran kuda dengan dosis 2,0 $\mathrm{kg}$ per $1 \mathrm{~m}^{2}$ lahan pada lahan pertanian yang akan ditanami kacang panjang.

Kata kunci: kompos kotoran kuda, pertumbuhan kacang pajang 


\section{Pendahuluan}

Ketersediaan unsur hara dalam tanah merupakan salah satu faktor yang dapat menentukan pertumbuhan dan produksi tanaman. Salah satu upaya yang dapat dilakukan dalam mengatasi kurangnya unsur hara adalah dengan pemberian kompos pada lahan pertanian. Hasil penelitian Rivai dan Wardani (2017) menunjukkan bahwa tanaman Alpinia malaccencis yang mendapat input nutrisi berupa kompos bioposka sebanyak $75 \%$ memiliki pertumbuhan vegetatif yang lebih cepat pada parameter tinggi tanaman, diameter batang, panjang daun, lebar daun dan jumlah daun dibandingkan dengan perlakuan lainnya. Selanjutnya kompos bilotong mampu meningkatkan waktu berbunga, jumlah buah pertanaman, dan bobot buah per hektar tanaman tomat (Nisaa et al, 2017). Dosis kompos berpengaruh nyata terhadap tinggi tanaman sawi pada umur 16 dan 40 hari setelah tanam (Habibi et al, 2017). Pemberian kompos berpengaruh nyata terhadap tinggi tanaman, umur berbunga, umur panen dan berat buah cabai rawit (Maruli et al, 2012). Interakasi urea dan kompos berpengaruh nyata terhadap pertumbuhan jagung tongkol ganda (Muyassir, 2013).

Salah satu komoditi sektor pertanian yang mampu memberikan kontribusi pada perekonomian Indonesia adalah produksi kacang panjang. Kacang panjang memiliki nilai ekonomi yang cukup tinggi dan menduduki urutan kedua setelah kedelai (Marzuki, 2007). Buah kacang panjang merupakan bahan sayuran yang dapat diolah menjadi berbagai macam masakan seperti sayur asam, sayur lodeh, pecel dan gado-gado. Selain itu buah kacang panjang dapat dikonsumsi mentah sebagai lalapan. Rasanya yang enak, renyah dan gurih, menyebabkan sayuran ini banyak disukai konsumen di desa maupun di kota (Harianto, 2007).

Sebagai sayuran kacang panjang merupakan sumber protein, energi, karbohidrat, dan lemak yang berguna untuk memenuhi gizi. Kacang panjang yang umumnya dipanen dalam bentuk polong muda banyak mengandung vitamin $a, b$ dan c, selanjutnya polong tua banyak mengandung protein. Kandungan nilai gizi pada kacang panjang yaitu protein $24 \mathrm{~g}$, energi $441 \mathrm{kal}$, karbohidrat $83,4 \mathrm{~g}$, lemak $2,3 \mathrm{~g}$, vitamin a $5535 \mathrm{mg}$, vitamin b 0,14 mg dan vitamin c 0,85 mg (Cahyono, 2005).

Berdasarkan uraian di atas maka peneliti melakukan penelitian tentang pengaruh kompos terhadap pertumbuhan kacang panjang yang dilakukan di Desa Sukarara Kecamatan Jonggat Kabupaten Lombok Tengah. Adapun tujuan dilaksanakannya penelitian ini adalah untuk mengetahui: (1) pengaruh kompos terhadap pertumbuhan kacang panjang, (2) dosis optimum kompos yang perlu diberikan pada lahan pertanian Desa Sukarare agar kacang panjang dapat tumbuh secara optimal.

\section{Bahan dan Metode}

Pada tahap awal peenelitian ini dilakukan pembuatan kompos dengan bahan baku kotoran kuda yang dilanjutkan dengan pemupukan kacang panjang menggunakan kompos kotoran kuda. Alatalat yang digunakan adalah cangkul, linggis, ember plastik, terpal, parang, sekop, sendok, gelas ukur, alat tulis menulis, timbangan, parang, hand spreyer, gunting karung goni dan karung nilon,. Selanjutnya bahan yang digunakan adalah dedak halus, sekam, air, kotoran kuda. mulsa plastik, benih kacang panjang, tanah sawah, insektisida, air dan bambu.

Dalam penelitian ini digunakan rancangan acak kelompok. Perlakuan kompos kotoran kuda terdiri atas 6 level yaitu: $\mathrm{K}_{\mathrm{o}}=$ tanpa pemberian kompos (kontrol), $\mathrm{K}_{1}=$ pemberian $0,5 \mathrm{~kg}$ kompos $/ 1 \mathrm{~m}^{2}$ lahan, $\mathrm{K}_{2}=$ pemberian $1,0 \mathrm{kgkompos} / 1 \mathrm{~m}^{2}$ lahan, $\mathrm{K}_{3}=$ pemberian $1,5 \mathrm{~kg}$ kompos $/ 1 \mathrm{~m}^{2}$ lahan, $\mathrm{K}_{4}=$ pemberian $2,0 \mathrm{~kg}$ kompos $/ 1 \mathrm{~m}^{2}$ lahan, $\mathrm{K}_{5}=$ pemberian 2,5 kg kompos $/ 1 \mathrm{~m}^{2}$ lahan, Setiap perlakuan dilakukan dengan 8 ulangan (Hanafiah, 1994). Adapun tahapan penggunaan kompos pada lahan pertanian adalah: (1) membersihkan lahan dari rumput, batang padi dan sampah lainnya, (2) membongkar lahan menggunkan cangkul, (3) membuat bedengan lahan dengan ukuran panjang $12 \mathrm{~cm}$ dan lebar $80 \mathrm{~cm}$, (4) memberikan kompos pada bedengan lahan sesuai dosis perlakuan, (5) mencampur kompos dan tanah pada lahan sampai tercampur secara merata, (6) menanam kacang panang pada media tanam yang sudah disiapkan, 
(7) mengukur parameter pertumbuhan kacang panjang.

Parameter pertumbuhan yang diukur adalah panjang batang, panjang anak daun, lebar anak daun dan jumlah anak daun yang dilakukan setelah tanaman berumur 20 hari. Data kuantitatif hasil pengukuran parameter pertumbuhan kacang panjang dianalisis dengan analisis sidik ragam (Toutenburg and Shalabh, 2009)

$$
\mathrm{F}_{\text {hitung }}=\frac{\text { Kuadrat Tengah Perlakuan }}{\text { Kuadrat Tengah Galat }}
$$

\section{Hasil dan Pembahasan}

Data hasil pengukuran parameter pertumbuhan (panjang batang) pada saat tanaman kacang panjang berumur 20 hari adalah sebagai berikut

Tabel 1. Data hasil pengukuran rerata panjang batang kacang panjangakibat perlakuan kompos

\begin{tabular}{ll}
\hline Perlakuan & Panjang Batang $(\mathrm{cm})$ \\
\hline $\mathrm{K}_{0}$ & 35,4 \\
$\mathrm{~K}_{1}$ & 36,8 \\
$\mathrm{~K}_{2}$ & 39,7 \\
$\mathrm{~K}_{3}$ & 41,6 \\
$\mathrm{~K}_{4}$ & 43,2 \\
$\mathrm{~K}_{5}$ & 42,6 \\
\hline
\end{tabular}

Hasil analisis data menunjukkan bahwa kacang panjang yang ditanam pada lahan percobaan tanpa perlakuan kompos memiliki rerata panjang batang $35,4 \mathrm{~cm}$. Selanjutnya pada lahan yang diberi kompos mulai dari pemberian $0,5 \mathrm{~kg}$ sampai dengan 2,0 kg kompos $/ 1 \mathrm{~m}^{2}$ lahan, rerata panjang batang meningkat sejalan dengan meningkatnya dosis kompos yang diberikan pada masing-masing lahan percobaan. Namun demikian mulai dari perlakuan 2,0 kg sampai dengan perlakuan $2,5 \mathrm{~kg}$ kompos, rerata panjang batang kacang panjang tidak menunjukkan adanya peningkatan Selanjutnya data hasil pengukuran panjang anak daun, lebar anak daun dan jumlah anak daun pada saat tanaman berumur 20 hari adalah sebagai berikut
Tabel 2. Data hasil pengukuran rerata panjang anak daun, lebar anak daun dan jumlah anak daun kacang panjang, akibat perlakuan kompos

\begin{tabular}{llll}
\hline Perlakuan & $\begin{array}{l}\text { Panjang } \\
\text { Anak Daun } \\
(\mathrm{mm})\end{array}$ & $\begin{array}{l}\text { Lebar } \\
\text { Anak Daun } \\
(\mathrm{mm})\end{array}$ & $\begin{array}{l}\text { Jumlah } \\
\text { anak daun } \\
\text { (lembar) }\end{array}$ \\
\hline K0 & 108 & 60 & 26 \\
K1 & 109 & 64 & 26 \\
K2 & 109 & 64 & 29 \\
K3 & 110 & 65 & 32 \\
K4 & 111 & 65 & 37 \\
K5 & 111 & 65 & 37 \\
\hline
\end{tabular}

Analisis sidik ragam pengaruh pemberian kompos terhadap parameter pertumbuhan menunjukkan bahwa pemberian kompos pada lahan pertanian Desa Sukarara tidak berpengaruh nyata terhadap panjang dan lebar anak daun kacang panjang pada umur 20 hari setelah tanam. Pemberian kompos berpengaruh nyata terhadap panjang batang dan jumlah anak daun kacang panjang pada umur 20 hari setelah tanam. Hasil penelitian ini sejalan dengan hasil penelitian yang dilakukan oleh sejumlah peneliti lainnya. Indriyati (2005) menyimpulkan bahwa pemberian pupuk kompos mampu meningkatkan pertumbuhan dan produksi padi di lahan pasang surut sulfat masam. Selanjutnya interaksi antara pupuk NPK dan pupuk kompos memberikan pengaruh nyata terhadap pertumbuhan gmelina baik tinggi maupun diameter (Wasis dan Fathia, 2010). Kompos UB berpengaruh nyata terhadap tinggi tanaman, jumlah daun, bobot segar total tanaman sawi dan bobot segar total kosumsi sawi. Perlakuan kompos UB menghasilkan tinggi tanaman sawi $18,26 \mathrm{~cm}$, bobot segar total tanaman sawi 39,24 g dan bobot segar total konsumsi sawi 25,55 g, lebih tinggi jika dibandingkan dengan tanpa kompos (Atari et al, 2017). Aplikasikompos azolla dan azolla segar sebagai pupuk organic memberikan pengaruh nyata terhadap pertumbuhan tanaman wortel pada parameter panjang tanaman, tinggi tanaman, jumlah daun dan indeks luas daun (Huda et al, 2016). Kedelai varietas galunggung merespon secara signifikan terhadap kompos limbah kelapa sawit, produksi meningkat secara sigifikan (Darma, 2000). Aplikasi kompos pada lahan pertanian Desa Montong Are berpengaruh signifikan terhadap pertumbuhan tomat (Raksun dan Mertha, 2017). 
Perlakuan tanah: kompos: pupuk kandang (1: 3 : 1) memberikan hasil terbaik pada parameter tinggi tanaman, jumlah stolon, jumlah buah panen, diameter buah dan derajat kemanisan pada tanman stroberi dibandingkan dengan perlakuan tanpa kompos (Sipayung et al, 2016). Perlakuan kompos 1,2 dan $3 \mathrm{~kg}$ lubang tanam ${ }^{-1}$ memperlihatkan tinggi tanaman jumlah anakan, panjang daun dan lebar daun yang berbeda nyata dibandingkan dengan kontrol (Burhanudin et al, 2016). Pemberian kompos berpengaruh nyata terhadap tinggi tanaman, panjang daun, lebar daun, diameter batang, waktu muncul bunga jantan dan bunga betina, panjang tongkol dan jumlah biji tanaman jagung manis (Syafriliandi et al, 2016). Media tanam dengan komposisi kompos dan tanah $(1: 2)$ dan penambahan pupuk $\mathrm{M}_{10}$ pada konsentrasi 20 $\mathrm{ml}$ mampu meningkatkan diameter batang $(2,29$ $\mathrm{mm})$ sedangkan pada konsentrasi $15 \mathrm{ml}$ meningkatkan produksi tongkol (1,66 buah) tanaman jagung saat panen (Elpawati et al, 2015). Aplikasi kompos yang dicampur dengan topsoil sebagai media tanam dengan dosis $1 / 2$ atau $2 / 3$ bagian dari media yang dikombinasikan dengan pupuk NPK 2 gr per bibit dapat meningkatkan tinggi dan diameter rata-rata bibit meranti tembaga asal cabutan alam sebesar $72 \%$ dan $42 \%$ dibandingkan tanpa kompos dan pupuk (Junaedi, 2012)

Rendahnya tinggi batang dan jumlah anak daun kacang panjang pada pada lahan pertanian tanpa pemberian kompos disebabkan oleh kurang optimalnya ketersediaan berbagai unsur hara pada lahan pertanian Desa Sukarara. Selanjutnya aplikasi kompos menyebabkan makin tersedianya unsur hara terutama sulfat dan nitrat yang berasal dari hasil pengurain kotoran ternak yang diproses menjadi kompos. Disamping itu pemberian kompos pada lahan pertanian dapat memperbaiki sifat fisika, kimia dan biologi tanah (Musnamar, 2003).

Hasil analisis data menunjukkan bahwa kadar optimum kompos yang perlu diberikan pada lahan pertanian Desa Sukarara Kecamatan Jonggat Kabupaten Lombok Tengah untuk meningkatkan pertumbuhan kacang panjang adalah 2,0 kg kompos untuk setiap $1 \mathrm{~m}^{2}$ lahan pertanian, karena perlakuan dengan dosis 2,0 $\mathrm{kg}$ kompos $/ 1 \quad \mathrm{~m}^{2}$ lahan memberikan panjang batang terpanjang dan jumlah anak daun terbanyak dibandingkan perlakuan yang lain.

\section{Kesimpulan}

Berdasarkan hasil analisis data dan pembahasan pada penelitian ini maka dapat disimpulkan bahwa: (1) penggunaan kompos pada lahan pertanian Desa Sukarare berpengaruh nyata terhadap panjang batang dan jumlah anak daun kacang panjang, (2) dosis optimum kompos yang perlu diberikan pada lahan pertanian Desa Sukarara agar kacang panjang dapat tumbuh secara optimal adalah 2,0 kg kompos untuk $1 \mathrm{~m}^{2}$ lahan pertanian. Berdasarkan hasil penelitian ini, direkomendasikan kepada petani di Desa Sukarara untuk menggunkan kompos kotoran kuda dengan dosis 2,0 kg per $1 \mathrm{~m}^{2}$ lahan pada lahan pertanian yang akan ditanami kacang panjang.

\section{Ucapan Terimakasih}

Termakasih yang sebesar-besarnya tim penulis sampaikan kepada Rektor Universitas Mataram yang telah memfasilitasi pelaksanaan penelitian ini dengan menyediakan dana penelitian. Terimakasih juga kami sampaikan kepada semua pihak yang telah membantu pelaksanaan penelitian ini

\section{Daftar Pustaka}

Atari, N., Murdiono, W.E., dan Koesriharti. 2017. Pengaruh Kompos UB dan Pupuk Nitrogen terhadap Pertumbuhan dan Hasil Tanaman Sawi Bunga. Produksi Tanaman, 5 (12): 1936 - 1941.

Burhanudin, Yudarfis dan Idris, H. 2016. Pengarug Pemberian Kapur dan Kompos terhadap Pertumbuhan dan Produksi Jahe Putih Besar pada Tanah Podsolik Merah Kuning. Bul Littro, 27 (1): 47 - 53

Cahyono, B. 2005. Kacang Panjang (Teknik Budidaya dan Analisis Usaha Tani). CV. Aneka Ilmu. Semarang.

Darma,S. 2000. Respon Tanaman Kedelai Terhadap Kompos Limbah Kelapa Sawit pada Dosis Berbeda. Budidaya Pertanian, 6(2): $96-104$

Elpawati, Dara, S.D. dan Dasumiati. 2015. Optimalisasi Penggunaan Pupuk Kompos 


$\begin{array}{llr}\text { dengan Penambahan } & \text { Effective } \\ \text { Microorganism } & 10 \quad \text { (EM10) } & \text { pada } \\ \text { Produktivitas } & \text { Tanaman } & \text { Jagung. }\end{array}$

Alkauniyah, 8 (2): 77 - 87

Habibi, Z., Satriawan, H dan Agusni. 2017. Pengaruh Dosis Kompos Terhadap Pertumbuhan tanaman sawi (Brassica rapa). Agrotropika Hayati, 4(4): 305 - 313.

Harianto. 2007. Pengantar Agronomi. Gramedia. Jakarta

Huda, M.S., Widaryanto, E. dan Nugroho, A. 2016. Pengaruh Beberapa Dosis Kompos dan Azolla (Azolla pinnata R.B.) Segar pada Pertumbuhan dan Hasil 2 Varietas Tanaman Wortel (Daucus carrota) L.). Produksi Tanaman, 4 (6): 431 - 437

Indriyati, L. 2005. Pengolahan Jerami Padi pada Pertanaman Padi Lahan Pasang Surut Sulfat Masam. Abstrak Hasil Penelitian Pertanian Indonesia Pusat Perpustakaan dan Penyebaran Hasil Penelitian Indonesia, 12 (2) Bogor.

Junaidi, A. 2012. Pengaruh Kompos dan Pupuk NPK terhadap Peningkatan Kualitas Bibit Cabutan Miq. Penelitian Hutan dan Konservasi Alam, 9 (4): 373 - 383

Maruli, Ernita dan Gultom, H. 2012. Pengaruh Pemberian NPK Grower dan Kompos terhadap Pertumbuhan dan Produksi Tanaman Cabai Rawit (Capsicum frustencen L.). Dinamika Pertanian, 27 (3): $149-155$

Marzuki, R. 2007. Bertanam Kacang Panjang. Penebar Swadaya. Jakarta

Musnamar, E.I. 2003. Pupuk Organik Padat. Penebar Swadaya. Jakarta.

Muyassir. 2013. Respon Jagung Tongkol Ganda terhadap Pemupukan Urea dan Kompos. Manejemen Sumberdaya Lahan, 2(3): $250-254$.

Nisaa, B., Sudiarso dan Ainin N. 2017. Aplikasi NPK Majemuk dan Kompos Bilotong untuk Meningkatkan Pertumbuhan dan Hasil Tomat (Solanum lycopersicum) Ditanaman Diantara Kubis (Brassica
Oleracea). Produksi Tanaman, 5 (6): 925 $-931$

Raksun, A. dan Mertha, I.G. 2017. Pengaruh Kompos Terhadap Hasil Panen Tomat (Lycopersicum esculentum Mill). J. Pijar MIPA, 13 (1): 56 - 59.

Rivai, R,M. dan Wardani, F.F. 2017. Aplikasi Pemanfaatan Pupuk Kompos pada Fase Vegetatif Tanaman Obat Alpinia malaccensis. Proseding Seminar Nasional Masy Biodiv Indon, 3 (1): 154 - 156

Sipayung, M., Ashari, H., Baskara, M. dan Heddy, S. 2016. Pengaruh Pemberian Kompos terhadap Pertumbuhan dan Hasil dua Varietas Stroberi (Fragaria, sp). Plantropica, 1 (2): 35 - 48

Syafriliandi, Murniati dan Idwar. 2016. Pengaruh Jenis Kompos terhadap Pertumbuhan dan Produksi Tanaman Jagung Manis. Jom Faperta, 3 (2): 1 - 9

Teutenburg, H. and Shalabh. 2009. Statistical Analysis of Designed Experiment. Third Edition. Springer. New York

Wasis, B. dan Fathia, N. 2010. Pengaruh Pupuk NPK dan Kompos terhadap Pertumbuhan Semai Gmelina (Gmelina arborea Roxb.). Ilmu Pertanian Indonesia, 16(2):123-129 